\title{
Descriptive Analysis of Introduction of Innovative Technologies in Forestry
}

\author{
Oleg M. Korchagin ${ }^{1}$, Irina S. Zinovieva ${ }^{1} \&$ Yuliya N. Popova ${ }^{1}$ \\ ${ }^{1}$ Voronezh State Academy of Forestry and Technologies, Voronezh, Russia \\ Correspondence: Oleg M. Korchagin, Voronezh State Academy of Forestry and Technologies, Timiryazeva st., 8, \\ Voronezh 394613, Russia. Tel: 7-0732-53-7498. E-mail: postmaster@julygb.vsi.ru
}

Received: September 1, 2014

Accepted: September 19, 2014 Online Published: November 14, 2014

doi:10.5539/ass.v10n23p208

URL: http://dx.doi.org/10.5539/ass.v10n23p208

\begin{abstract}
The problem of innovative development of the most important area of forestry is reforestation. Established that questions the use of innovative technologies in reforestation and afforestation in Russia is still not well defined. One promising avenue is the use of planting material with closed root system (MCS). However, for the development and practical application of technological innovation requires financial support, due to the high cost of produce seed with MCS. As evidence of the economic cost calculation done on the basis of compiled cash-flow sheets on growing seedlings with open and closed root systems and the establishment of forest plantations biennial seedlings ACS and PCL-year seedlings grown in containers with a volume of cells 150, 200, 300 and $400 \mathrm{~cm} 3$ conditions and non-heated greenhouses. The authors revealed that the main factor of the cost of seedlings with MCS is the costs for the maintenance of machines and mechanisms, i.e. organization costs of purchasing and maintaining expensive greenhouses. It is proved that the cost of producing the annual container planting material (MCS) and the subsequent development of forest plantations is not significantly different from the receipt of annual and biennial seedlings from bare-root in a greenhouse covered ground, but its practical application in silviculture production gives a whole other opportunities related primarily from a significant reduction in terms of the cultivation of seed and seedlings of high adaptability. It is proved that the establishment of forest cultures seedlings with MCS is only possible with the support of the state, i.e. through the mechanism of public-private partnerships.
\end{abstract}

Keywords: innovative technologies of forest cultivation, planting with closed root system, public-private partnership

\section{Introduction}

Reforestation and afforestation are some of the most important aspects of forestry. Size and rate of reforestation is primarily determined by the level of development and degree of intensity of forest management. An important place in the process of reforestation and afforestation is given planting materials. Over the past forty years in the world, the most widespread technology for growing planting material mainly softwood (pine, spruce) with closed root system (MCS) in small containers in greenhouses and nurseries complexes where planting material provides the necessary climate, timely watering and fertilizing.

In Canada, Finland, Sweden and Norway, forest planting more than $90 \%$ is carried out using technology seedlings to the MCS. At the same time, as the experience of the Nordic countries, production cost pipelined seedlings is less than that of seedlings grown in the open (Driesshe, 1976).

At the same time, the lack of this technology in Russia is its relatively high cost of implementation, due to the use as a raw material of elite seeds of the 1st class, as well as the need for a high level of mechanization and automation of the processes of growing, transporting on silvicultural area and landing (Selimenkov, 2011).

Today, the economic issues of seedlings with MCS in Russia are not well defined. Despite the fact that the economy of growing crops in forest nurseries in different periods devoted their labors V.A. Cherstvin (1951), NA Smirnov (1969), A. Zviedre, G.A. Igaunis (1981) LS Kovalev et al. (1992) and many other scientists who study the cost of growing oak porch with MCS have been conducted. Modern research in this area conducted E.N. Lobanova $(1997,1998)$ and V. Balkova $(2001,2004)$, A.V. Zhigunov, (2000, 2007), however, they relate to the study of the economy growing mainly conifers in the forest zone, while the hardwoods, and in particular the 
English oak is the predominant species in a sparsely wooded area of the Russian Federation, and hence the cost items on its cultivation can be different (Zhirunov, 2000; Zhigunov, 2011).

Despite the greater the cost of cultivation of planting material with MCS, by reducing the number of seats per 1 hectare and a reduction, due to a better survival rate, the cost of addition of forest cultures and cultural care, a generalized reduction of costs for forest management activities by approximately $15 \%$.

In addition, increases the production of forest crops as planting material can be planted throughout the growing season.

As the researchers note of this problem one important advantage of seedlings with MCS is to reduce the cost of caring for forest plantations. Despite the fact that in the early stages of seedlings with closed root system more expensive, the cost of crops with closed root system twice cheaper than traditionally grown seedlings - estimates suggest experts. If the squares with conventional seedlings for the summer need to spend at least 2 or 3 swaths weeding, for the crops grown in the packages - it is a maximum of 2 swaths. Weeding them do not need to, that is a big plus, since this work is extremely tedious and exhausting.

The main advantages of the technology of growing of planting material with MCS compared with the traditional Russian methods known in the art for a long time, and the adaptation of planting material with MCS in the cultures with the forestry point of view for the domestic environment to be successful (Senkov, 2011).

At the same time, more research is needed to substantiate the direct production costs of growing seedlings of English oak. Require detailing the costs of establishing plantations with planting material grown with MCS. Necessary to provide an analysis of costs and benefits of seedlings with MCS in comparison with other technologies of cultivation (ACS) used in forestry sparsely wooded area.

\section{Method}

Growing seedlings (seedlings) for planting is done in forest nurseries.

Determination of cost-effectiveness for seedlings in forest nurseries done in order to:

- $\quad$ study the economic feasibility creation of new or reconstruction of existing nurseries;

- choosing the best option seedlings;

- establish the actual cost-effectiveness evaluation of economic activity existing nurseries.

For the present study the calculation of economic efficiency of seedlings with MCS is advantageously carried out in stages. The first step is to determine the efficiency of cultivation of planting material, calculating the price of seedlings grown with MCS. At the same time as an investment in growing seedlings with MCS to take the full cost of production and the possibility of planting material. When calculating the total cost of the investment tab kennel (capital investments for the acquisition of fixed assets, etc.) are recognized indirectly through depreciation. This stage is implemented as part of this report.

The second stage involves determining the effectiveness of the project for growing seedlings with MCS in a greenhouse (heated and unheated) in a previously defined product prices. The implementation of this phase, according to the contractual obligations assumed in 2014.

Then the calculation of the actual economic efficiency should include:

- To provide data on the actual sources and amounts of investment and actually received effects;

- A comparison of the effectiveness of the existing calculation option.

Indicators of economic benefit is defined in terms of value due to additional production obtained in the forestry and related industries; preventable damage to the environment and material production; cost savings for the production of works and services.

In determining the economic effect of the conditions of production are used:

- Existing wholesale and retail prices, tariffs on products and services;

- The legislation in force regulations fee labor and natural resources;

- Existing regulations deductions from profit organizations in the state and local budgets;

- Rules and settlement companies with the bank for providing loan or deposit its own funds, etc.

Current expenditure on the creation of products are calculated in the field of production in accordance with the regulations in their calculation.

Then the efficiency of the process of planting English oak can be set based on two fundamental points:

- The comparative effectiveness of seedlings with closed (MCS) and open (ACS) of the root system;

- The comparative effectiveness of various technologies of the plantation porch with ACS and PCL. 
To assess the growing porch on a particular technology used indicator of profitability, defined by the formula:

$$
\mathrm{R}=\left(\mathrm{P} / \mathrm{C}^{*}\right) 100 \%
$$

where $P$ is profit from the sale of planting material;

$C$ is cost of cultivation of planting material.

At the same time it should be noted that the choice of a particular technique of creating cultures (in this case with the PCL or ACS) should be guided not only an indicator of cost but these survival and growth of seedlings. New technology may be acceptable only if it does not reduce the effectiveness of the forestry crops.

Weak survival and slow growth after planting crops may instead cost savings result in losses due to the need of additional care.

Comparative effectiveness of various technological; creation schemes for crops is determined by the formula:

$$
\text { Emid }=(\mathrm{C} 1-\mathrm{C} 2) * \mathrm{TP}
$$

where $E_{\text {mid }}$ is annual effect, rub.; $C_{1}$ and $C_{2}$ is the cost of crops, respectively, the old and new technologies; $T P$ is annual growing porch with ACS.

\section{Results}

Let's calculate the economic costs were made up cash-flow map for growing seedlings with ACS and the PCL and the establishment of forest plantations biennial seedlings ACS and PCL-year seedlings grown in containers with a volume of cells 150,200,300 and $400 \mathrm{~cm} 3$ in a heated and non-heated greenhouses.

Already in the intermediate stages of the calculations, and found that the cost of production of seedlings with MCS in unheated greenhouses for depreciation exceeds the production cost of seedlings with ACS in 2 or more times. In this regard, it has been suggested that the structure of the business growing seedlings on new technology - PCL and built at their own expense LSSTS (greenhouse) is not attractive compared with the cultivation of seedlings on old technology in the open ground of the forest nursery.

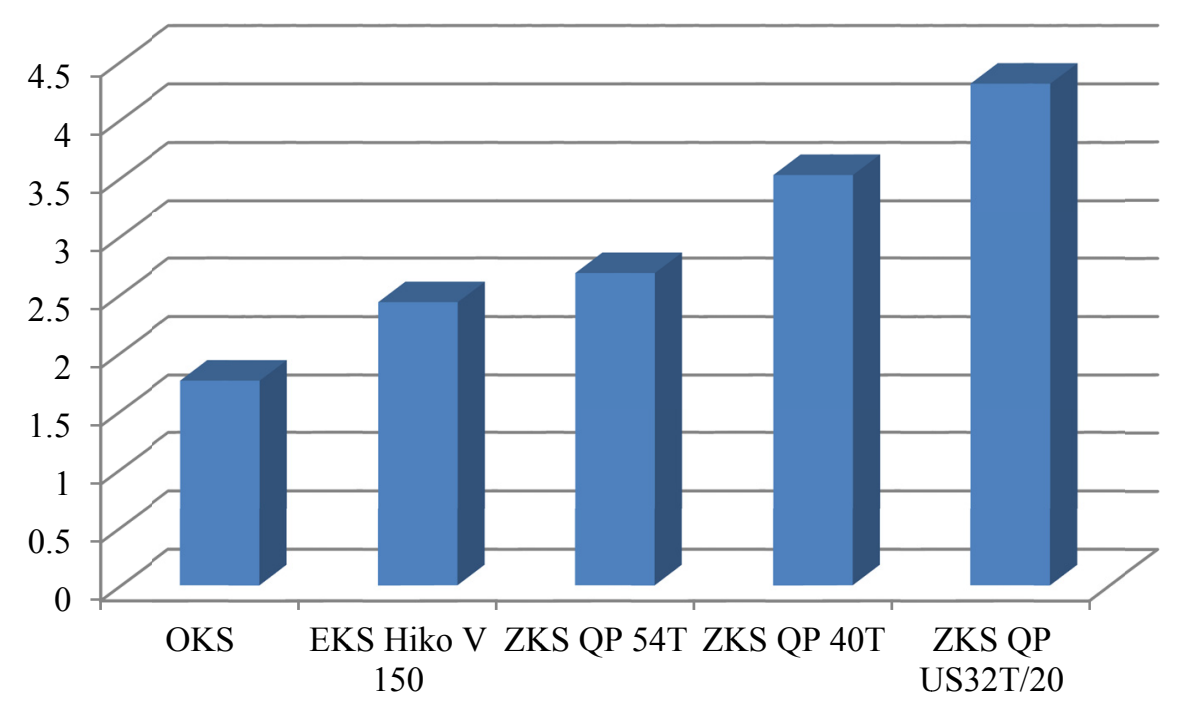

Figure 1. Production costs of oak seedlings with ACS and PCL with different volumes of cells in the container for depreciation provided growing without the use of heating

It was found that the main factor of the cost of seedlings with MCS is the costs for the maintenance of machines and mechanisms, i.e. organization costs of purchasing and maintaining expensive greenhouses.

Further, similar calculations were carried out without taking into account depreciation, which would require substantiation implementing PPPs.

Characteristically, the cost of production of seedlings with MCS excluding depreciation will be significantly lower than the cost of raising seedlings with ACS and make container QP 54T - 0,60 rub. / Pcs without heating and 1.48 rub. / Pcs. heating. 
It has been found that the use of the heating system leads to an increase in costs on the average $1.5-2.5$ times. However, it becomes possible to increase the yield of seedlings per unit area. Increasing the production economy achieved by growing area in the greenhouse greenhouse more than one crop per year. This requires greenhouse heating, which allows you to start growing the first crop already before the usual growing season. This increase in the volume of production, of course, requires some investment.

Growing seedlings PCL leads to reduce the complexity of production and, consequently, contributes to automation of production processes.

With increase of the cell is an increase in material costs and reducing costs to the seed.

Thus, the reserve to reduce the cost of seedlings with the PCL is the further automation of the process, input universal equipment in order to reduce the use of accelerated depreciation and the methods of its calculation.

So, in the first phase found that the use of new technologies - Heating porch under greenhouse conditions, closed root system leads to an increase in production costs and increased costs. Advantage in terms of cost while the seedlings grown in forest nurseries and not LSSTS. Moreover, the cost of production of seedlings depends essentially on the depreciation in case of application of the cost of depreciation of the seedlings significantly lower (Table 1). Then businessmen invest forest production in the construction of LSSTS will be less competitive (especially for the price) with products grown on the old technology. Next, we determined the rates of forest products based on the demand and the prevailing price on the oak seedlings. In this case, found that the price of oak seedlings with MCS does not depend on the growth conditions (heated or unheated), and will be significantly lower only in the absence of the depreciation rate, which confirmed the previously stated assumption.

Table 1. Economic indicators for growing plantations of oak seedlings with ACS and MCS depending on the use of heat in the greenhouse and the use of depreciation

\begin{tabular}{|c|c|c|c|c|c|}
\hline \multirow{3}{*}{ Indicators } & \multirow{3}{*}{$\begin{array}{l}\text { Seedlings } \\
\text { OKS }\end{array}$} & \multicolumn{4}{|c|}{ Seedlings grown under LSSTS } \\
\hline & & \multicolumn{2}{|c|}{ Without heating } & \multicolumn{2}{|c|}{ With heating } \\
\hline & & $\begin{array}{c}\text { With } \\
\text { amortization }\end{array}$ & $\begin{array}{c}\text { Without } \\
\text { amortization }\end{array}$ & $\begin{array}{c}\text { With } \\
\text { amortization } \\
\end{array}$ & $\begin{array}{c}\text { Without } \\
\text { amortization }\end{array}$ \\
\hline \multicolumn{6}{|c|}{ Costs for growing oak seedlings } \\
\hline $\begin{array}{c}\text { Contents of machinery and } \\
\text { equipment, rub. }\end{array}$ & 90640 & 6178192 & 154701 & 8727406 & 2703739 \\
\hline Wages, $\mathrm{p}$ & 99889 & 284267 & 284267 & 284267 & 284267 \\
\hline Materials, $\mathrm{p}$ & 183279 & 886250 & 886250 & 886250 & 886250 \\
\hline Total cost, $\mathrm{p}$ & 373808 & 7348709 & 1325218 & 9897923 & 3874256 \\
\hline $\begin{array}{l}\text { Output standard planting } \\
\text { material, thousand. / Ha }\end{array}$ & 300 & 2900 & 2900 & 2900 & 2900 \\
\hline $\begin{array}{l}\text { Cost of production per unit } \\
\text { of output, p. }\end{array}$ & 1,25 & 2,53 & 0,46 & 3,41 & 1,33 \\
\hline \multicolumn{6}{|c|}{ Formation of wholesale prices for seedlings } \\
\hline administrative expenses & 0,63 & 1,01 & 0,18 & 1,36 & 0,53 \\
\hline $\begin{array}{l}\text { Selling and distribution } \\
\text { expenses }\end{array}$ & 0,13 & 0,25 & 0,05 & 0,34 & 0,13 \\
\hline The total cost, rub. & 2,01 & 3,79 & 0,69 & 5,11 & 1,99 \\
\hline Profit rub. & 0,30 & 0,57 & 0,10 & 0,77 & 0,30 \\
\hline $\begin{array}{l}\text { Wholesale selling price of } \\
\text { seedlings with VAT, EUR }\end{array}$ & 2,73 & 5,14 & 0,93 & 6,94 & 2,70 \\
\hline \multicolumn{6}{|c|}{ Costs of creating plantations } \\
\hline Total costs AUD. & 19113 & 16081 & 7800 & 19161 & 10845 \\
\hline $\begin{array}{l}\text { Planting density, volume / } \\
\text { ha }\end{array}$ & 4000 & 3500 & 3500 & 3500 & 3500 \\
\hline $\begin{array}{l}\text { Unit cost of production } \\
\text { (silviculture), p, incl. }\end{array}$ & 4.78 & 4.59 & 2.23 & 5.47 & 3.10 \\
\hline
\end{tabular}

Analysis of the cash-flow sheets of oak seedlings with MCS and ACS allowed install: 
Firstly, growing seedlings of oak with MCS is more costly process compared to seedlings with ACS in respect of the technique - the cost of a machine-shifts above 15.6 times and labor costs - the cost in people / day in 2 above seven times.

Secondly, to tree seedlings with MCS prevails highly specialized equipment that determines the high demand for skilled workers and purchasing expensive equipment. Aggregate economic performance, production cost Bookmarks plantations of oak seedlings with ACS and MCS depending on the use of heating in greenhouses and the use of depreciation in the table. Price growing unity of planting material or bookmark 1 hectare of forest crops equals major cost (the cost of the process), increased by the amount of SG \& A expenses and taking into account the rate of profit.

Thus, the selling price of a seedling grown with ACS is 2.73 rubles. VAT and VAT 2.31 rubles The sales price of the seedling with MCS range from 0.93 rubles to 6.94 rubles. VAT and from 0.79 to 5.88 rubles in greenhouses with heating and without it. Profitability Bookmarks forest crops is presented in Table 3.

Table 2. Indicators of profitability Bookmarks forest crops seedlings of English oak with MCS (type containers QP 54T (16)) and with OCS

\begin{tabular}{|c|c|c|c|c|c|}
\hline \multirow{3}{*}{ Indicators } & \multirow{3}{*}{$\begin{array}{l}\text { Seedlings } \\
\text { OKS }\end{array}$} & \multicolumn{4}{|c|}{ Seedlings ZKS } \\
\hline & & \multicolumn{2}{|c|}{ Without heating } & \multicolumn{2}{|c|}{ With heating } \\
\hline & & $\begin{array}{c}\text { With } \\
\text { amortization }\end{array}$ & $\begin{array}{c}\text { Without } \\
\text { amortization }\end{array}$ & $\begin{array}{c}\text { With } \\
\text { amortization }\end{array}$ & $\begin{array}{c}\text { Without } \\
\text { amortization }\end{array}$ \\
\hline $\begin{array}{l}\text { Unit cost of production, } \\
\text { rub. }\end{array}$ & 4.78 & 4.59 & 2.23 & 5.47 & 3.10 \\
\hline The total cost, rub. & 7.17 & 6.89 & 3.34 & 8.21 & 4.65 \\
\hline Profit rub. & 1.08 & 1.03 & 0.50 & 1.23 & 0.70 \\
\hline $\begin{array}{l}\text { Wholesale selling price of } \\
\text { seedlings without VAT, } \\
\text { EUR. }\end{array}$ & 8.25 & 7.92 & 3.84 & 9.44 & 5.35 \\
\hline $\begin{array}{l}\text { Wholesale selling price of } \\
\text { seedlings with VAT, EUR }\end{array}$ & 9.74 & 9.35 & 4.53 & 11.14 & 6.31 \\
\hline The level of profitability & 0.15 & 0.15 & 0.15 & 0.15 & 0.15 \\
\hline $\begin{array}{l}\text { Comparable return on the } \\
\text { price of OKS }\end{array}$ & 0.15 & 0.20 & 1.47 & 0.005 & 0.77 \\
\hline
\end{tabular}

In the calculations of the relative profitability of the plantation of English oak seedlings started from the assumption that, to ensure the competitiveness of planting material for the price, the latter forest crops grown with MCS should match the price of forest cultures grown with ACS.

Then the calculation of the relative profitability of production as the base will use the price of seedlings with ACS equal to 8.25 rubles. VAT.

Analyzing the data of the calculations, it becomes clear that the relative profitability of growing forest plantations with MCS lower than ACS in case of depreciation.

Excluding amortization margin growing forest crops seedlings PCL is 0.77 (for seedlings grown in greenhouses heated) or 1.47 (for seedlings grown in greenhouses without heating) compared with the level of profitability of growing of forest cultures seedlings with ACS.

Calculation of the relative efficiency of growing plantations of English oak, created porch with MCS and OKS is presented in Table 3.

Thus, economically justified growing seedlings in containers with MCS type QP 54T $(\mathrm{h}=16 \mathrm{~cm})$ in a unheated greenhouse. In this case, the expected economic effect will be 15320 rubles. / Ha, with one turn of the year. When growing seedlings with MCS in a heated greenhouse to ensure positive results is necessary to provide more than 1 rotation in the back of the PM. 
Table 3. Comparative effectiveness crop of English oak

\begin{tabular}{cccccc}
\hline & & \multicolumn{3}{c}{ Seedlings ZKS in LSSTS } \\
\cline { 3 - 5 } Indicators & $\begin{array}{c}\text { Seedlings } \\
\text { OKS }\end{array}$ & \multicolumn{2}{c}{ Without heating } & \multicolumn{2}{c}{ With heating } \\
\cline { 3 - 5 } & & $\begin{array}{c}\text { With } \\
\text { amortization }\end{array}$ & $\begin{array}{c}\text { Without } \\
\text { amortization }\end{array}$ & $\begin{array}{c}\text { With } \\
\text { amortization }\end{array}$ & $\begin{array}{c}\text { Without } \\
\text { amortization }\end{array}$ \\
\hline $\begin{array}{c}\text { The total cost of the } \\
\text { unit, rub. }\end{array}$ & 7.17 & 6.89 & 3.34 & 8.21 & 4.65 \\
$\begin{array}{c}\text { The total cost, rub. the } \\
\text { entire volume, rub. }\end{array}$ & 28680 & 24115 & 11690 & 28735 & 16275 \\
Comparative effect, rub. & - & 1120 & 15320 & -4160 & 10080 \\
\hline
\end{tabular}

Growing oak seedlings with MCS obtaining makes the greatest possible economic benefit in the case of the formation of the full cost and price, excluding depreciation charges. This is convincingly demonstrated by the results we performed calculations to determine the comparative economic effects of seedlings grown in a forest seed selection centers (LSSTS).

\section{Discussion}

The widespread introduction of new technologies of artificial reforestation would be superior to the traditional, primarily ensured by the availability of quality planting material. 6 Due to these production of container seedlings for planting is a promising direction (Ushnurtsev, 2004). Implementation of agro-technology techniques for the production of annual container planting material (PCL) practically does not differ from the receipt of annual and biennial seedlings from bare-root in a greenhouse covered ground, but its practical application in silviculture production gives a whole other possibilities. However, the products (seeds and seedlings with MCS) is planned to implement the organizations engaged in forestry activities (reforestation) on the basis of a state contract (within the state order), as well as tenants of the forest areas, who are responsible for execution of works on reforestation, it needs to be competitive in the first place at a price that is comparable in cost with seedlings grown in nursery conditions. The implementation of this condition in practice is only possible in the institutions in which the fund holder is the state.

Importantly, we have demonstrated with the estimated cost of depreciation and without taking them into account. The basis for these calculations is that LSSTS, created in 2010, were organized as separate legal entities in the form of state budgetary institutions, with funding from the state budget. In this regard, it is applicable to generate the cost of seedlings, excluding depreciation and amortization (p. $1 \&$ 3, claim 2, Art. 256 of the Tax Code, is not subject to amortization: "Property acquired (created) with the use of budget funds earmarked funding. Specified norm does not apply to the property received by the taxpayer during the privatization") (Mariev, 2012). In subsequent years, the practice of creating LSSTS financing from public funds has been suspended, which in our opinion, does not contribute to solving the problems of reforestation. Thus, cost of cultivation of planting material, and as a consequence, the price of seedlings depends on financial support from the state and the legal form in which to act LSSTS. It should be noted that the Ministry of Finance believes that the growing seedlings material- is entrepreneurship, so forest seed centers for their money must build businesses, and the state within the state order to acquire their planting materials for state needs (Morkovina, 2014).

This position is a declarative, economically unjustified and, if implemented, could lead not only to the consequences of the crisis in reforestation, but also completely destroy entrepreneurship in forestry, which, for obvious reasons, cannot exist without state support. In this connection, it should recognize the need for government involvement in the creation of LSSTS through the mechanism of public-private partnerships.

\section{Conclusion}

With the establishment of forest crops of oak seedlings with MCS grown under both unheated and heated greenhouses, obtaining economic benefit possible in the case of the formation of the full cost and price, excluding depreciation charges. The implementation of this condition in practice is only possible in the institutions in which the fund holder is the state.

Thus, the establishment of forest cultures seedlings with MCS is only possible with the support of the state, ie through the mechanism of public-private partnerships. 
In this regard, the establishment of seed selection centers, with the involvement of public-private partnership in the Russian Federation is the only true through the introduction of innovative technologies in forestry and forestry support entrepreneurship. Only with the participation of the state will be possible to accumulate in a single manufacturing facility regions forest seed plots and plantations, to ensure the production of seeds and growing seedlings of forest plants with improved hereditary properties and increase entrepreneurial activity in forestry.

\section{References}

Driesshe. R. (1976). Prediction of cold hardness in Douglas fir seedlings by index of injury and conductivity methods. Forest, 4(1), 511-515.

Selimenkov, R. Y., \& Mironov, A. V. (2011). The effectiveness of innovative technologies in the cultivation of forests. Region's economy: Problems and prospects, 3(55), 51-57

Gradyatskas, A. I. (1998). Experience artificial regeneration of oak in Lithuania. Oak - breed of the third millennium: Coll. scientific. Works IL NASB, 48(1), S.157-160

Zhirunov, A. V. (2000). Theory and practice of growing planting material with closed root system. St. Petersburg: $\mathrm{SPbNIILH}$.

Zhigunov, A. V., Saksa, T., \& Sved, J. (2011). Fundamentals of container tree sedling production. St. Petersburg, Suonenjoki: St. Petersburg Forestry Research Instituty.

Senkov, A. O. (2011). Adaptation of Scots pine seedlings with closed root system on clearcuts middle taiga subzone: Author. dis. Candidate. p. / x. Sciences: 06.03.01. Arkhangelsk.

Ushnurtsev, A. V. (2004). Growing seedlings of pine and larch container for planting in the Republic of Mordovia. Dis. Candidate. Agricultural Sciences: 06.03.01: Yoshkar-Ola.

Mariev, A. N. (2012). Tree breeding and seed production centers - ideology, problems and prospects. Report. International Conference "Renewable Wood Resources: innovative development in forestry" 6-8 June 2012, St. Petersburg, Russia. Retrieved from http://greenpressa.ru/viewtopic.php?f $=4 \& \mathrm{t}=968$

Morkovina S. S. (2014). Cluster approach to basis of forms of cooperation of the state and entrepreneurship in the forestry management of the sparsely wooded region. Life Science Journal, 11(10s), 423-427.

\section{Copyrights}

Copyright for this article is retained by the author(s), with first publication rights granted to the journal.

This is an open-access article distributed under the terms and conditions of the Creative Commons Attribution license (http://creativecommons.org/licenses/by/3.0/). 